UNDERGRADUATE RESEARCH IN NATURAL AND CLINICAL SCIENCE AND TECHNOLOGY (URNCST) JOURNAL Read more URNCST Journal articles and submit your own today at: https://www.urncst.com

\title{
Introducing a Novel Research Education Initiative: The URNCST Journal Research Methods Primer
}

Neethu Pavithran, HBSc [1], Ankush Sharma, BSc Student [1], Vedish Soni, BHSc Student [1], Umair Majid, MSc, MEd, PhD Candidate [1], Jeremy Y. Ng, MSc, PhD [1]**

[1] URNCST Journal, Toronto, Ontario, Canada

*Corresponding Author: $\underline{\text { editor@urncst.com }}$

Note: Correction added after original version published on November 03, 2021. We regret any inconvenience caused.

\begin{abstract}
The Undergraduate Research in Natural and Clinical Science and Technology (URNCST) Journal Research Methods Primer is a novel undergraduate research design education opportunity available to undergraduate and professional-undergraduate degree students internationally. Applicants are invited to submit an abstract on a research method pre-selected by the journal and learn from a graduate-level researcher with expertise and interest in the research area. The three-month initiative is aimed at actively supporting and mentoring students as they navigate the complexities of research method theory and practice. The mentor and mentee(s) collaborate throughout the course of the program, culminating in the development of a full-length research methods primer manuscript of publishable quality. In this brief editorial, we provide an overview of how our editorial team successfully conceptualized, cultivated, and prepared for the launch of this initiative.
\end{abstract}

Keywords: research methods primer; research method; research education; undergraduate journal; undergraduate research; URNCST Journal

\section{Introduction}

The Undergraduate Research in Natural and Clinical Science and Technology (URNCST) Journal Research Methods Primer program provides students with the opportunity to gain a deeper understanding of a research method of interest and partake in a comprehensive mentorship from a graduate-level researcher with expertise in the method. The three-month program also allows for undergraduate students to write and submit a manuscript to the URNCST Journal, as well as receive and address peerreviewed feedback, culminating in the publication of a fulllength article. A research method can briefly be defined as a strategy, process or technique used to collect and analyze data for the purpose of discovering new information. Within the context of this initiative, eligible research methods will be pertinent to the fields of natural and clinical sciences and technology, and may describe any aspect of the scientific process. It is acknowledged that certain research methods are highly broad and/or complex, in which case, a series of primer manuscripts may be written on these topic areas (i.e. systematic reviews, clinical trials). Lastly, articles on the usage of software in research are also eligible. As part of the journal's commitment to provide unique and novel initiatives in research education, the Research Methods Primer program was developed in response to the fact that a need exists for undergraduatelevel researchers to gain a fundamental understanding of research methods that will prepare them for a future, successful career as a graduate student and scientist. The majority of the limited research opportunities that exist for undergraduate researchers tend to not prioritize the learning of research methods. Instead, they often involve being onboarded in the midst of an ongoing project, typically with responsibilities dedicated solely to the data collection/analysis portions of a study, precluding them from developing a holistic understanding of the methods used to conduct high-quality research. As a result, our editorial board observed that by the end of their degree programs, many undergraduate students, even those with extensive research experience, more often than not have a minimal understanding of designing and conceptualizing research projects, identifying the appropriate methodology to answer a research question, and justifying their series of actions taken when conducting a research project. In addition, it is not uncommon for undergraduate researchers to make the decision to attend graduate school with little understanding and experience of writing a full-length manuscript and addressing received peer-reviewed feedback. The Research Methods Primer program was specifically designed to address these knowledge gaps found within undergraduate research by both actively supporting and mentoring students in gaining a deeper understanding of research method theory and practice, as 
UNDERGRADUATE RESEARCH IN NATURAL AND CLINICAL SCIENCE AND TECHNOLOGY (URNCST) JOURNAL Read more URNCST Journal articles and submit your own today at: https://www.urncst.com

well as through the development of accessible, published educational resources for all future early-career researchers.

\section{Eligibility and Application Process}

The Undergraduate Research in Natural and Clinical Science and Technology (URNCST) Journal Research Methods Primer program is open to individuals enrolled in undergraduate (i.e. BSc, BEng, BA) and professionalundergraduate (i.e. MD, DDS, PharmD, OD, RN) degree programs. At the beginning of each of the 3 annual cohorts (summer, fall, winter) of the program, the URNCST Journal announces a call for abstract submissions. Prior to the start of each cohort, graduate-level researchers are invited to provide a specific research method of focus, relating to their area(s) of interest and expertise. For the submission application, the graduate-level mentors are asked to provide two to four peer-reviewed published research articles that summarize their research method with a high degree of quality; subsequently, these graduate-level researchers serve as mentors to the participants accepted into the program that submitted abstracts corresponding to their method of focus. A finalized list of research methods and their associated articles provided by each mentor, are publicly listed on the URNCST Journal website. Applicants are invited to individually draft and submit an abstract which involves summarizing the research articles selected by the mentors relating to one of the method topics, and submit their work for consideration. The abstracts are then evaluated by the respective graduate-level mentors who assign a score using a rubric provided on the application form. Accordingly, successful applicants must exhibit a suitable degree of academic writing ability as well as a readiness to learn about the method that they selected in greater detail by reviewing the provided peer-reviewed articles. Mentors will select the applicant(s) with high scores on their abstract submission evaluations as their respective mentee(s) to partake in the program. Applicants are expected to partake in a three-month mentorship period, during which time they will learn about their respective research method under the supervision of their mentor with the end goal of writing a full-length research methods primer manuscript that will be formally submitted to the URNCST Journal.

The three-month mentorship period will culminate with the mentor and mentee(s) submitting their final manuscripts to the URNCST Journal. An internal editor or associate editor will evaluate the manuscript for quality and if satisfactory, will send the article out for peer review. Otherwise, the submission will be returned to the authors for further refinement. Once the peer reviewers have completed their assessment, their feedback is shared with the authors. The undergraduate mentee(s) is/are able to consult and collaborate with their mentors to appropriately address the critiques before re-submitting a revised draft to the journal. An internal editor or associate editor will once again render an editorial decision, moving to either accept, request additional revisions, or reject the resubmitted manuscript for publication. Every effort is made to encourage and support participants to get to the point where their manuscripts are deemed to be of publishable quality, even if this necessitates multiple rounds of revisions on the authors' parts.

\section{Promoting the Initiative: The Role of Engagement Officers}

Making sure that potential students are aware of the opportunity is one of the most critical parts of the URNCST Journal Research Methods Primer. For this purpose, engagement officers (EOs) are vital to the daily operations of the URNCST Journal, as they carry out the promotional tasks for the program. EOs are assigned tasks on a weekly basis; the tasks vary in accordance to the specific stage of the program scheduled by the journal's editorial team. The target audience for the URNCST Journal Research Methods Primer program is undergraduate students with an interest in research design, conceptualization, and methods. As many of the EOs are also students in undergraduate programs themselves, they are encouraged to conduct their promotional tasks at student-based events taking place at their respective institutions, as well as student-centric social media platforms and groups.

\section{Standardizing Promotion and Managing Abstract Submissions: The Role of Engagement Leads}

Engagement Leads (EL) are a group of three to five senior team members that supervise the EOs and report directly to the editor-in-chief of the URNCST Journal. ELs were previous EOs with a certain level of seniority and experience that displayed a high level of responsibility and dedication to furthering the URNCST Journal's mission. ELs' primary responsibilities involve assigning weekly tasks to the EOs, tracking their progress, and holding them accountable for their work. Additionally, ELs track EO activity to ensure that EOs do not promote in a way that could be considered spam (e.g. through "doublepromoting"), and vets promotional material to ensure all journal communications are sent out with a high degree of quality and professionalism. ELs meet with the editor-inchief and deputy editor on a weekly basis to understand the needs of the program and delegate tasks to EOs, troubleshoot any promotional issues that may occur, set deadlines for EOs, and manage the previously allocated and continuing tasks within the journal. Once the call for abstracts submissions for the Research Methods Primer program closes, ELs are responsible for sorting the submissions by research method and performing preliminary checks for completion before sending them to their respective mentors for evaluation. 
UNDERGRADUATE RESEARCH IN NATURAL AND CLINICAL SCIENCE AND TECHNOLOGY (URNCST) JOURNAL Read more URNCST Journal articles and submit your own today at: https://www.urncst.com

\section{Developing Schedules for Mentees and Mentors: Routine Check-ins \& "Block" Schedule Design}

The URNCST Journal Research Methods Primer program schedule was designed to occur three times annually (summer, fall, winter), whereby each round is comprised of a three-month mentorship period. The program schedule (Table 1) outlines the timeline of deliverables distributed throughout the duration of the mentorship period. It was designed to ensure both accountability as well as adequate time for the completion of the bi-weekly milestone tasks expected from the participants, culminating in a full-length manuscript to be submitted to the journal at the end of the program. The schedule was systematized in a block format, whereby the three months of the mentorship period was divided into six blocks (two weeks per block), plus a "pre-block preparation" period. Mentors are provided with the program schedule a month in advance of the mentorship period they will participate in, detailing a breakdown of the respective deliverables expected from both mentor and mentee(s) following each individual block.

Pre-block preparations are required by both mentor and mentee(s) prior to their initial introductory meeting in block one (Table 1). For mentors, these preliminary tasks involve developing a slide deck presentation outlining the key points associated with their research method of focus. Mentors are advised to ensure that their slide deck content is comprehensible at an undergraduate student level, as the mentee(s) may have minimal prior understanding of the research method. During this period, the mentee(s) is/are expected to familiarize themselves with the research method of focus, using the peer-reviewed articles selected by their mentor for the abstract submission stage. For the mentee(s), the aim of the pre-block period is to allow for time in advance to address any knowledge gaps they may have regarding their research method. Any questions can be subsequently clarified with their mentor during their initial meeting prior to the start of the manuscript writing process.

At the beginning of block one, a representative from the URNCST Journal sends out introductory emails to connect mentors with the mentee(s) they agreed to supervise, at which point the participants are responsible for scheduling their initial meetings via phone/video call at their earliest conveniences. The first block/initial meet is when mentors present their slide deck, discuss expectations and program schedule, provide critical feedback on their mentees' original abstract submissions, as well as field any questions the mentee(s) may have. At this point, the teams will also determine the ideal frequency of meetings required over the span of the next three months.

The program schedule was intentionally designed to account for the timeline of a student concurrently pursuing a full-time undergraduate degree. As a result, flexibility was a key consideration when creating the Research Methods Primer block schedule; participants are able to work towards the completion of their tasks at any time
Table 1. URNCST Journal Research Methods Primer Schedule

\begin{tabular}{|c|c|}
\hline Block & Deliverables \\
\hline $\begin{array}{l}\text { Pre-Blocks } \\
\text { Preparation }\end{array}$ & $\begin{array}{l}\text { 1. Design short slide deck ( } 15-20 \text { slides) } \\
\text { describing the key points associated with the } \\
\text { selected research method (mentor) } \\
\text { 2. Complete a detailed read of the } 2-4 \text { research } \\
\text { articles originally provided by the mentor } \\
\text { (mentee) }\end{array}$ \\
\hline $\begin{array}{l}\text { Block } 1 \\
\text { (Weeks 1-2) }\end{array}$ & $\begin{array}{l}\text { 1. Hold introductory meeting (mentor and } \\
\text { mentee), present slide deck to mentees and } \\
\text { field any questions (mentor) } \\
\text { 2. Provide mentee with feedback on their } \\
\text { originally submitted abstract, i.e. what } \\
\text { aspect(s) of the research method they } \\
\text { understood well/may require clarification } \\
\text { (mentor) } \\
\text { 3. Discuss expectations/meeting schedule } \\
\text { (mentor and mentee) }\end{array}$ \\
\hline $\begin{array}{l}\text { Block } 2 \\
\text { (Weeks 3-4) }\end{array}$ & $\begin{array}{l}\text { 1. Conduct literature search to identify relevant } \\
\text { literature about the research method (mentee } \\
\text { with guidance from mentor) } \\
\text { 2. Compile list of potential references to cite in } \\
\text { the final paper and develop an annotated } \\
\text { bibliography, begin writing the manuscript } \\
\text { (mentee) } \\
\text { 3. Draft rough dot jot outline that describes the } \\
\text { outline of the research methods primer } \\
\text { including a short list of literature that could be } \\
\text { cited in the final paper (mentor and mentee) }\end{array}$ \\
\hline $\begin{array}{l}\text { Block } 3 \\
\text { (Weeks 5-6) }\end{array}$ & $\begin{array}{l}\text { 1. Provide feedback on literature } \\
\text { search/reference list and rough dot jot } \\
\text { outline (mentor) } \\
\text { 2. Finish writing Introduction \& Utility } \\
\text { sections of the manuscript (mentee and } \\
\text { mentor) }\end{array}$ \\
\hline $\begin{array}{l}\text { Block } 4 \\
\text { (Weeks 7-8) }\end{array}$ & $\begin{array}{l}\text { 1. Provide feedback on Introduction \& Utility } \\
\text { sections of the manuscript (mentor) } \\
\text { 2. Begin writing Challenges \& Limitations } \\
\text { sections of the manuscript (mentee) }\end{array}$ \\
\hline $\begin{array}{l}\text { Block } 5 \\
\text { (Weeks 9-10) }\end{array}$ & $\begin{array}{l}\text { 1. Finish writing Challenges \& Limitations } \\
\text { sections of the manuscript (mentee and } \\
\text { mentor) } \\
\text { 2. Provide feedback on Challenges \& } \\
\text { Limitations sections of the manuscript } \\
\text { (mentor) }\end{array}$ \\
\hline $\begin{array}{l}\text { Block } 6 \\
\text { (Weeks 11-12) }\end{array}$ & $\begin{array}{l}\text { 1. Complete all final revisions/edits of the } \\
\text { manuscript (mentee); at this point the } \\
\text { mentor should ensure factual accuracy and } \\
\text { revise sections written by mentees } \\
\text { accordingly (mentor) } \\
\text { 2. Format manuscript accordingly to URNCST } \\
\text { Journal submission guidelines (mentee) } \\
\text { 3. Review over formatted manuscript (mentor) } \\
\text { 4. Submit manuscript (mentee) }\end{array}$ \\
\hline
\end{tabular}


UNDERGRADUATE RESEARCH IN NATURAL AND CLINICAL SCIENCE AND TECHNOLOGY (URNCST) JOURNAL Read more URNCST Journal articles and submit your own today at: https://www.urncst.com

during the two week period of any given block, which accounts for participants' competing obligations. The consistency of the two week deadlines for each interval of new deliverables also allows for participant accountability and serves to prevent the participant from completing all tasks at the last minute. As an added measure, URNCST Journal representatives send check-in emails to mentors at the start of blocks two to six so that our internal team can also monitor each teams' progression throughout the course of the program.

\section{Conclusion}

The novel Research Methods Primer program was developed in line with the URNCST Journal's mission to encourage and support undergraduate research internationally. This initiative was designed to address the knowledge gap between undergraduate and graduate-level research, allowing students to gain a deeper understanding of research method theory and practice crucial to an undergraduate researcher's success as a future scientist. This program also allows undergraduate students to make a more informed decision about whether to pursue future graduate-level research education. Additionally, this initiative provides graduate student mentors with opportunities to engage in undergraduate mentorship and hone their supervisory skill sets, which is an activity expected of graduate trainees seeking faculty positions in academic institutions post-graduation.

\section{List of Abbreviations Used}

URNCST: Undergraduate Research in Natural and Clinical

Science and Technology

EO: engagement officer

EL: engagement lead

\section{Conflicts of Interest}

The authors declare that they have no conflict of interests.

\section{Authors' Contributions}

NP: is currently a Deputy Editor for the URNCST Journal, co-drafted the manuscript, and gave final approval of the version to be published

AS: is currently an Assistant Editor for the URNCST Journal, co-drafted the manuscript, and gave final approval of the version to be published

VS: is currently an Assistant Editor and the Development and Communications Liaison for the URNCST Journal, codrafted the manuscript, and gave final approval of the version to be published

UM: is the Managing Editor of the URNCST Journal, critically revised the manuscript, and gave final approval of the version to be published.

JYN: is the founding Editor-in-Chief of the URNCST Journal, critically revised the manuscript, and gave final approval of the version to be published

Please outline the contributions made by each author using the following format, where each author is referred to by their initials:

\section{Acknowledgements}

We would like to acknowledge all engagement officers, assistant editors, and associate editors who have generously contributed their time and efforts to the publication, without whom the URNCST Journal Research Methods Primer initiative would not be possible.

\section{Article Information}

Managing Editor: Jeremy Y. Ng

Article Dates: Published Nov 0321

\section{Citation}

Please cite this article as follows:

Pavithran N, Sharma A, Soni V, Majid U, Ng JY. Introducing a novel research education initiative: The URNCST Journal Research Methods Primer. URNCST Journal. 2021 Nov 03: 5(11). https://urncst.com/index.php/urncst/article/view/330 DOI Link: https://doi.org/10.26685/urncst.330

\section{Copyright}

(C) Neethu Pavithran, Ankush Sharma, Vedish Soni, Umair Majid, Jeremy Y. Ng. (2021). Published first in the Undergraduate Research in Natural and Clinical Science and Technology (URNCST) Journal. This is an open access article distributed under the terms of the Creative Commons Attribution License (https://creativecommons.org/licenses/by/4.0/), which permits unrestricted use, distribution, and reproduction in any medium, provided the original work, first published in the Undergraduate Research in Natural and Clinical Science and Technology (URNCST) Journal, is properly cited. The complete bibliographic information, a link to the original publication on http://www.urncst.com, as well as this copyright and license information must be included. 


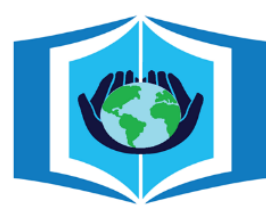

\section{URNCST Journal \\ "Research in Earnest"}

\section{Funded by the \\ Government of Canada}

Canadắ

Do you research in earnest? Submit your next undergraduate research article to the URNCST Journal!

| Open Access | Peer-Reviewed | Rapid Turnaround Time | International | | Broad and Multidisciplinary | Indexed | Innovative | Social Media Promoted |

Pre-submission inquiries? Send us an email at info@ urncst.com | Facebook, Twitter and LinkedIn: @URNCST

Submit YOUR manuscript today at https://www.urncst.com! 